\title{
CONTRIBUTIONS TO OUR KNOWLEDGE OF THE SMALLER MARINE ALGAE
}

\author{
By R. W. Butcher, B.Sc. \\ Ministry of Agriculture and Fisheries, Nottingham
}

(Plates I and II)

\section{INTRODUCTION AND METHODS OF IsOLATION}

Our lack of knowledge of nanoplankton organisms is due largely, no doubt, to the necessity for examining them alive and the comparative difficulty of observing them, and also to their being, apparently, of no more than indirect importance in the ecology of fishes, except when their occasional presence in great abundance has been accompanied by unfavourable hydrographical changes. An adequate survey of life in the sea is bound to take them into account. Since they are frequently abundant, at least in inshore waters, and propagate rapidly, they probably form an important constituent of the food of adult filter-feeding invertebrates. They are likely to be of still greater importance as the essential food of many planktonic larvae, particularly in the early stages. Oyster larvae (Ostrea edulis L.) can ingest nothing larger than about Io $\mu$ and appear to rely for food on minute flagellates (Cole, 1936, 1939; Bruce, Knight \& Parke, 1940). The food of other marine larvae has not been closely investigated.

Routine estimates of nanoplankton abundance have for some years formed part of investigations into the factors associated with good growth and survival of oyster larvae in the oyster-breeding tanks of the Ministry of Agriculture and Fisheries at Conway and in oyster-producing estuaries of Cornwall and Essex. The method used has been to concentrate a water sample quantitatively, by filtering through a Gradocol collodion membrane with the aid of an exhaust pump, and then to count the organisms in subsamples of the concentrate, using a haemacytometer (Cole \& Knight Jones, 1949). The work has been hampered by lack of information concerning the systematics of nanoplankton organisms. The majority of those observed are of undescribed species and many belong to new genera. The affinities of some of the commonest minute flagellates are obscure. The present account is the initial result of efforts which are being made to fill this gap in our knowledge.

Most flagellates alter in shape and lose their flagella on treatment with many fixatives and become virtually unrecognizable, though I \% osmic acid may give satisfactory results; they must therefore be examined alive. Since they are rapidly motile for long periods and can be studied adequately only under 
a $2 \mathrm{~mm}$. objective, the work has so far been confined to forms from which thick cultures could be obtained.

The culture medium used has been sea-water Erdschreiber (see Gross, 1937). Serial dilution of sea-water samples into test-tubes of Erdschreiber proved to be the most useful method of isolating new cultures. This method, outlined below, is based on that used in the bacteriological examination of water supplies (Ministry of Health, I940).

For a nanoplankton of from I to 30 organisms per $\mathrm{mm}^{3}$ (the density most frequently encountered), a preliminary dilution of $\mathrm{I} / \mathrm{IOO}$ was made; $\mathrm{I} \mathrm{ml}$. of the sea-water sample was added to $99 \mathrm{ml}$. of sterile sea water in a sterile stoppered bottle and shaken by inverting twenty-five times. Fifteen test-tubes, plugged with cotton-wool, sterilized and each containing $9 \mathrm{ml}$. of sterile Erdschreiber, had previously been prepared and arranged in three batches of five. With a sterile pipette I $\mathrm{ml}$. of the preliminary dilution was added to each test-tube of the first batch. Then, with a fresh pipette, the contents were mixed by sucking up and down ten times and I ml. was transferred to a tube of the second batch. This process was repeated for the remaining four tubes in each of the first and second batches, using the same pipette. Then with a fresh pipette and following the same procedure, I ml. was transferred from each test-tube of the second batch to a tube of the third batch.

The three batches of test-tubes then contained, respectively, dilutions of I/I000, I/I0,000 and I/I00,000, i.e. approximately IO, I and $0 . \mathrm{I} \mathrm{mm} .^{3}$ of the original sea water. They were placed in windows facing north. Exposure to direct sunlight, even for short periods when the sun was low, or for a few minutes only when the sun was high, often proved fatal to small flagellates. A series of test-tubes hung in a south window, but not exposed to direct sunshine, did not develop such a variety of organisms as a similar series in a north window. Apparently the wide temperature variations and the high light intensity in south windows are unfavourable to many forms. Cultures maintained at Nottingham grew well when kept in a cabinet at $12^{\circ} \mathrm{C}$., under constant illumination from two 20-W. warm white tubes.

It was found that thick cultures usually developed in some of the test-tubes from the dilution series after I-2 months in summer and 2-4 months in winter. Those of the first batch generally contained mixtures of organisms, while those of the third batch were often blank, but a few uni-algal cultures were usually obtained from the second and third batches.

Subcultures were made every 2 or 3 months, into either test-tubes or $150 \mathrm{ml}$. flasks. Although cultures in the larger vessels usually appeared more thriving and required less frequent attention, it was necessary, because of lack of space, to use test-tubes for the routine maintenance of cultures. It was found that many organisms could be maintained in mixed cultures, provided subculturing was carried out frequently. Some were subsequently isolated from these by making dilutions at favourable times. Some non-motile forms and larger 
flagellates were isolated by picking out single cells or groups of cells with fine pipettes under a high-power dissecting microscope, followed by washing in successive drops of sterile medium.

Platymonas apiculata n.sp. was positively phototactic when first observed, and a few thousand specimens, introduced into a large volume of sterile sea water, and left undisturbed, assembled on the side nearest to the light in a visible green cloud. Successive washings, taking advantage of this habit, produced a culture which contained only one other flagellate.

Plates of solid medium (Erdschreiber with $2 \%$ agar) were prepared and inoculated with diluted sea water. No growth of motile flagellates was obtained, but Nitzschia ovalis Arnott, N. longissima Ralfs, Synechocystis bacillaris n.sp., and an encysted strain of Platymonas apiculata were isolated by this method.

The quantitative dilution method described above is similar to that used by bacteriologists for estimating the numbers of bacteria in water samples. A count of the number of test-tubes developing cultures in each of the three batches indicates the probable number of organisms in the original sample. This can be found from statistical tables in the Ministry of Health's publication (1940), which were recalculated and provided with their standard errors by Swaroop (1938). With nanoplankton organisms and present-day culture methods it is unwarranted to assume that all the organisms introduced into the test-tubes survive and multiply, and this method has given estimated nanoplankton densities less than those obtained from haemacytometer counts of concentrated samples.

In the taxonomic study of these organisms three things have greatly simplified their examination. The first was the discovery of a new method of staining flagella. A drop of a suspension of the organism was placed on a slide and to this was added a drop of $\mathrm{I} \%$ osmic acid followed by a drop of a new methylene blue dye which was kindly supplied by Messrs Imperial Chemical Industries Ltd. This dye is alkaline and soluble in sea water. It was found that the flagella almost always stained a bright blue and the contents were often little altered.

The second discovery is due to Reynolds (1950), who has devised a solution which induces, in many algae, the formation of zoospores. This solution has been most useful in the identification of Ulothrix and other filamentous forms.

The third discovery was that, if glass slips were inserted in the culture solutions in the test-tubes, many of the non-motile organisms readily grew on them and they could subsequently be withdrawn, examined and mounted, more or less permanently, either stained or unstained. Inoculations of a new culture could be made with a splinter of a glass slip chosen visually under a dissecting microscope and the glass slip with adhering algae could be inserted in the spore-inducing solution with minimum disturbance. 
The author's very best thanks are due to Mr Knight Jones, who was largely responsible for the introduction and the section on methods of isolation; also to him and $\mathrm{Dr} \mathrm{H}$. A. Cole for supplying and maintaining many of the cultures of the organisms here described; to Prof. Pringsheim for suggestions in the early stage of this work; to Dr M. Parke for cultures and suggestions; and especially to his friend $\mathrm{Mr} \mathrm{N}$. Y. Sandwith for great help in preparing the Latin diagnoses.

\section{CHLOROPHYCEAE}

\section{CHLAMYDOMONADACEAE}

\section{Platymonas West}

\section{P. apiculata n.sp. (Pl. I, figs. I-5).}

Cellula compressa, a fronte visa late elliptica antice apice profunde biloba, flagellis 4 e sulco cylindrico exorientibus; chromatophoro campaniformi juventute laevis sed senectute granulis cum pyrenoide basali et multis amyli granulis dispersis praedito; stigmate singulo parte anteriore inserto, aurantiaco; cysto I-2 cellulis cum membrana externa crassa et stratifera praedito. Cellulis $7.5-10.5 \mu \times 6.5-8.5 \mu \times 4.5-5 \mu$.

Cells elliptical or narrowly oval, somewhat compressed, apex two-lobed with a deep furrow from which the flagella arise; pyrenoid large, conspicuous, situated at base of cell; chromatophore campanulate, single, bi-lobed, smooth in young individuals but coarsely granular in cells from old cultures. Eye-spot situated in upper portion of cell, orange; cells contain also numerous starch grains and two to six deeply staining granules near the furrow similar to those recorded by Carter (1937) for $P$. tetrathele West; flagella four, arising from base of furrow, I- I $\frac{1}{2}$ times as long as cell; cysts common in culture, one- or twocelled, surrounded by a thick, sometimes stratified, cell wall with an apical papilla.

In the shell-fish tanks at Conway, North Wales, in an aquarium at Lowestoft, and in the estuaries of the Helford River and the Crouch, apparently common.

This organism bears considerable resemblance to $P$. gracilis Kylin (1935) in size and position of eye-spot, but the apex is two-lobed and the presence of a papilla, usual in Chlamydomonas, has been recorded in this genus only for P. cordiformis (Carter) Korch. (Skuja, 1948) and it may well be present in other species. Carter (1937) is doubtful whether the lobing of the apex used by Kylin to divide the genus is a sound taxonomic character, but in all the strains of this new species which have been examined there is no doubt about the two-lobed apex and it would therefore appear correct to distinguish it from Platymonas gracilis.

The four strains of this organism which have been isolated vary somewhat in their behaviour in culture solutions. Every strain sooner or later becomes 
encysted but, even under what are apparently identical conditions, the time that elapses before all motile forms do so varies with every culture. In young vigorous cultures the chloroplast is almost smooth with very few starch grains but, on ageing, starch grains become more numerous and large green granules collect in considerable numbers in the cells.

The processes of division and encystment seem to be as follows. A cell becomes quiescent and sheds its flagella, while at the same time the compression becomes less obvious and the apical lobe shallow, so that, very shortly, the cell wall is entire and the cells scarcely compressed. Division takes place at an oblique angle and as the cells grow they move round, so that in mature cells the dividing wall is often horizontal. The daughter cells acquire flagella while they are still within the parent cell, and may at times be seen moving about before liberation. Liberation occurs by the splitting in half of the mother cell wall. When the cultures are old, single-celled cysts are the rule. These are not compressed, have a thick stratified cell wall and are filled with starch granules and other large spherical bodies which may possibly be oil.

\section{CHLORELLACEAE}

\section{Chlorella Beijerinck}

Unicellular green forms, of spherical or ovoid shape, are among the commonest of algae found developing in liquid cultures. Several such forms have been isolated from the River Crouch and elsewhere. All those now described have been under observation for a long time and have been grown in several strengths of solution, including Reynolds's spore-inducing solution, and the only form of reproduction which has been observed was by the production of non-motile bodies.

\section{Subgenus Euchlorella Wille}

C. salina n.sp. (P1. I, figs. II-I4).

Cellula sphaeroidea, membrana externa tenui; chromatophoro laete viridi clare, phialiformi, parietali, cellulam fere implente; pyrenoide centrali, magna. Incrementum est per cellulae materis in 8 cellulas filias divisionem. Cellula 4-7 $\mu$ diametro.

Cells spherical; surrounded by an obvious but thin, smooth, cell wall; chromatophore saucer-shaped, almost filling cell, bright green, finely granular; pyrenoid central, large, surrounded by starch sheath.

Propagation by the successive division of the mother cell into eight daughter cells which free themselves by the bursting of the parent wall.

This organism developed in cultures from the Conway tanks. It bears a superficial likeness to $C$. vulgaris Beijerinck, but the cell wall is apparently thinner and the chromatophore rather different in shape. As it is a marine organism, it seems reasonable to distinguish it as a separate species. 
C. stigmatophora n.sp. (P1. I, figs. 30-34).

Cellula sphaeroidea vel aliquantum elongata, membrana externa tenui; chromatophoro laete viridi claro, phialiformi, cellulam fere implente sed depressione terminali praedito; pyrenoide manifesta, amyli capsula circumdata centrali nisi in cellulis elongatis, stigmate fusco, in cellulis parvis singulo, stigmatibus in cellulis majoribus 2 vel ultra plerumque terminalibus. Incrementum est per cellulae matris in 2 vel 4 cellulas filias divisionem. Cellula 4-6 $\mu$ diametro.

Cells spheroidal to somewhat elongate, $3-5 \mu$ diameter, bright green, surrounded by smooth, thin cell wall; chromatophore saucer-shaped, filling most of cell but with depression at one end, rather granular; pyrenoid conspicuous, medium sized, central, though in the elongate cells rather to one end, surrounded by starch sheath; stigma single in young cells, two or more in the larger cells, usually at one end.

Propagation by division of mother cell into two, or more rarely four, daughter cells which are liberated by the bursting of the cell wall.

This was first isolated by Dr Parke (Bruce et al. I940) from a sea-water sample collected at Port Erin, Isle of Man, and there referred to as Chlorella sp. Subsequently it has been found in the River Crouch, Essex.

In its size and method of division this plant is not unlike $C$. spärckii Alvik (I934), but it is clearly marked off from all other described species of Chlorella by the presence of at least one dark brown body which is interpreted here as a stigma.

\section{Subgenus Chloroideum Nadson}

C. ovalis n.sp. (Pl. I, figs. I5-22).

Cellula ovata vel ellipsoidea, membrana externa tenui; chromatophoro laete viridi, parietali, paulum lobato, cellulam $\frac{3}{4}$ implente. Pyrenoide nulla. Incrementem est per cellulae matris in 8 cellulas filias divisionem. Cellula 3-5 $\mu \times 5-10 \mu$.

Cells ovoid to ellipsoidal, surrounded by a smooth hyaline cell wall; chromatophore parietal, bright green, smooth, slightly lobed, occupying about $\frac{3}{4}$ of the cell and, especially in young individuals, with a hyaline space at one end. Pyrenoid absent.

Propagation by successive division of the mother cell in individuals of Io $\mu$ diameter into eight daughter cells which free themselves by the bursting of the cell wall.

First isolated from the River Crouch, Essex, and apparently common in that district.

This differs from $C$. spärckii Alvik in the division of the mother cell into eight and not two daughter cells. Another closely related species is C. saccharophila Kruger (1894), but from the somewhat inadequate description his organism seems to be $15-20 \mu$ diameter with a granular chloroplast. 
C. marina n.sp. (Pl. I, figs. 6-IO).

Cellula ovata, membrana externa tenui, glabra; chromatophoro laete viridi, parietali, lobato, granuloso fere totam cellulam implente. Pyrenoide nulla sed corpore ut videtur olei in cellulis maturis. Incrementum est per cellulae matris in 8 vel I6 cellulas filias divisionem. Cellula $4-6 \mu \times 7-10 \mu$.

Cells ovoid, bright green, surrounded by smooth, hyaline cell wall; chromatophore an irregular parietal plate occupying almost all the cell, markedly and finely granular. Pyrenoid not observed, but in the mature cells definite hyaline bodies are present which appear to be oil.

Propagation by the successive division of individuals $10 \mu$ in diameter into eight or sixteen daughter cells which are liberated by the bursting of the cell wall.

This organism appeared in the cultures of a flagellate originally isolated at Port Erin by Dr Parke.

This species is closely allied to the last from which it differs in its granular chromatophore and spherical oil-like bodies.

\section{Nannochloris Naumann}

N. maculatus n.sp. (Pl. I, figs. 23-25).

Cellula sphaerica vel elongata, membrana externa tenui laevi; chromatophoro pallide viridi phialiformi, granuloso fere totam cellulam implente. Pyrenoide nulla visa; sed granulis amyli et oleorum. Incrementum est per cellulae matris in 2 cellulas filias divisionem. Cellula $3 \mu$ diametro.

Mature cells spherical or slightly elongate, surrounded by smooth cell wall; chromatophore pale green, cup-shaped, finely granular, occupying most of cell. No pyrenoid has been observed, but the cells contain both starch grains and other refractive bodies which are probably oil. Cells $3 \mu$ diameter.

Propagation by division of the cell into two individuals of about $3 \mu$ diameter.

First isolated from River Crouch, and common in saline ditches of that district.

The genus Nannochloris was established by Naumann (I93I) to include two very minute Chlorella-like organisms in which the cells divided only into two, and there was no evidence of a surrounding mother-cell membrane. As far as can be ascertained in such small cells, the above species has this same characteristic, while in addition it has been possible to ascertain, in part, the internal structure. Whilst it is about the same size and shape as Naumann's Nannochloris coccoides, its occurrence in sea water appears sufficient evidence that it is a different species.

N. atomus n.sp. (Pl. I, figs. 27-29).

Cellula minuta spheroidea membrana externa tenui; chromatophoro pallide viridi phialiformi, cellulam fere implente; pyrenoide non visa. Incrementum est per cellulae matris in 2 cellulas filias divisionem. Cellula $3 \mu$ diametro. 
Cells spheroidal, $2-3 \mu$ diameter, pale green surrounded by smooth thin cell wall. Chromatophore saucer-shaped, filling almost the whole cell, finely granular. Pyrenoid not observed.

Propagation by division of cells $3 \mu$ diameter into two daughter cells.

First isolated in dilution cultures from River Crouch and apparently widely distributed in that district.

This is another very minute member of the Chlorellaceae which has the same general characters as the last except that it is even smaller and the numerous starch grains and similar bodies are apparently absent.

S. cylindricus n.sp. (Pl. I, fig. 26).

\section{Stichococcus Naeg.}

Cellula cylindrica membrana externa tenui, laevi; chromatophoro laete viridi, parietali, laevi, cellulam totam implente. Pyrenoide nulla; nucleo minuto. Incrementum est per cellulae matris in 2 cellulas filias divisionem; filamento brevissimo, facile fracto. Cellula $2 \mu \times 3-4 \mu$.

Cells cylindrical with rounded truncate ends, cell wall thin, hyaline; chromatophore parietal, bright green, smooth, completely filling cell; pyrenoid absent; nucleus small, difficult to detect.

Propagation by the transverse division of the mother cell into two equal halves; filament very short, easily fragmenting. Cells $2 \mu \times 3-4.5 \mu$.

Isolated from River Crouch, Essex.

This organism in many respects occupies a position intermediate between a species of Nannochloris such as N. bacillaris Naum. and Stichococcus bacillaris Naeg. which shows a similar slight tendency to form filaments. A very thin mother-cell wall can occasionally be distinguished between the cells, though it appears to be short-lived. Absence of such a mother-cell wall is one of the chief characters of the former genus. Species of Stichococcus are usually terrestrial and this form, being both aquatic and marine, is clearly a wellmarked new species.

\section{CHRYSOPHYCEAE}

CHROMULINACEAE

Chromulina Cienkowsky

C. pusilla n.sp. (P1. II, fig. 42).

Cellula minuta, sphaeroidea dorsiventraliter paulum depressa, chromatophoro singulo, parietali, phialiformi, fulvo; flagello singulo, $2-3 \mu$ longo ut videtur secus marginem superiorem lateris applanati inserto; corpore fusco centrali. Cystis sphaeroideis membrana externa laevi. Cellula I-I.5 diametro.

Cells rounded, with definite dorsi-ventral flattening, $\mathrm{I}-\mathrm{I} \cdot 5 \mu$ diameter, periplast firm. Chromatophore single, parietal, saucer-shaped, filling most of 
cell. Flagellum single, 2-3 $\mu$ long, apparently inserted along upper edge of flattened side; chromatophore brownish green, single, apparently a parietal plate, filling about two-thirds of cell. The only other cell structure which can be made out in this small organism is a central dark granule the nature of which it is difficult to decide. Cysts endogenous, rounded, wall smooth, unsculptured.

Propagation by vertical division of the cells.

This, or some organism closely related to it, is apparently widely distributed, as it has been obtained repeatedly in cultures from Conway, the Helford River, Cornwall, and the River Crouch, Essex. The greatest density recorded by the serial dilution method previously described was 3500 per ml. in October 1946 from Cornwall. In addition, minute flagellates probably of this species are regularly observed in plankton counts from the Conway tanks and the Essex estuaries.

The assignment of this organism to its true position is a matter of some difficulty as, in so small a species, the cell contents are very hard to define. The general brownish colour of the suspensions in mass and the greenish brown colour of the individuals, together with the simple organization of the cells, suggest a close relationship to Chromulina, an alliance also confirmed by the apparent formation of cysts. Against placing the organism in this genus is the unilateral compression of the cells and the apparently lateral insertion of the flagellum. Though these are important characteristics, the fact that Chromulina includes species of varied shape seems to justify the inclusion of this species within the genus.

C. pusilla differs from C. pleiades Parke (1949) in having one chromatophore only, as well as in the absence of vibrating bodies, and it differs from this and C. parvula Conrad (1930) by its flattened side, and from all other described species in its very small size.

\section{OCHROMONADACEAE}

Pavlova n.gen.

Cellula solitaria, natante, nuda periplasto differentia carente praedita forma mutabili; 2 flagellis, dissimilibus, plusminusve lateraliter insertis.

Cells solitary, motile, naked with undifferentiated periplast; strongly metabolic. Flagella 2, unequal, inserted more or less laterally.

P. gyrans n.sp. (P1. II, figs. 35-38).

Cellula mutabili, elongata, aut ovata, aut amoeboidea, compressa, posteriore acuta; chromatophoris 2, magnis, fulvis, lateralibus, cum multis granulis dispersis; flagellis 2 dissimilibus, plusminusve lateraliter insertis; altero longiore apicem versus, altero breviore extrorsus provecto; parte apicali anteriore vacuolo contractili et stigmate singulo rubro praedita; parte basali posteriore granulis leucosini I-2 praedita. Cellula $3-6 \mu \times 4-\mathrm{IO} \mu$. 
Cells strongly metabolic, either elongated, ovoid or amoeboid, usually compressed, base acute; chromatophores two, large, lateral, not extending to the base, dull yellow, granular; flagella two, unequal and inserted at some distance below the apex, the larger directed towards the apex and the shorter outwards; a conspicuous red stigma and a small contracting vacuole are present in the apical region; at the posterior end one to three leucosin bodies are present.

Propagation is by longitudinal division in the non-motile stage.

Isolated from the Helford River, Cornwall, in I947.

This flagellate is most closely allied to the metabolic forms of Ochromonas, but differs in the sublateral insertion of the flagella, a character deemed of sufficient importance to separate it from this genus.

The metabolism of the individuals is so marked and the shape so varied that the form of the cells is anything from cylindrical compressed to almost spherical and amoeboid. Only the most frequently observed shapes are illustrated (Pl. II, Figs. 35-38).

Of the two flagella the one directed forward has a somewhat slow undulatory motion and can be seen without difficulty. It is about twice as long as the cell. The smaller flagellum is directed outwards and has a rapid up and down movement; in length it about equals the width of the cell and is very much more difficult to detect than the longer flagellum. The movements of the organism are very varied. Sometimes it twists and turns on its own axis, or goes forward with a vibratory motion, while at other times it moves rapidly in one direction. Or it may execute a combination of any of these movements.

A palmelloid state has been occasionally observed in cultures. The outline of the cells is then very irregular, but stigma and leucosin are very conspicuous.

The cells are very sensitive to all fixatives, in which they either become spherical or burst. In excess light on the microscope slide the cells behave as follows. Motion ceases and the elongate cells become oval or spherical, the long flagellum floats away and part of the hyaline contents of the cell is extruded through the periplast to form elongate or club-shaped 'pseudopodia'. Some individuals do not immediately lose their power of motion but continue to move with pseudopodia protruding. Apparently this form of the organism may best be considered a pathological condition.

\section{CRYPTOPHYCEAE}

\section{CRYPTOMONADACEAE}

\section{Hillea Schiller}

H. marina n.sp. (Pl. II, figs. 39-4I)

Cellula spherica vel ovata, lateraliter depressa; depressione lata haud profunda a margine apicali lateris applanati deorsum per quartam cellulae partem 
recte decurrente; 2 flagellis disparibus ex apice depressionis exorientibus; chromatophoro singulo, disciformi; parietali, fulvo, lobato granulis praedito; nucleo posteriore manifesto; pyrenoide centrali. Cellula $2 \mu \times 2.5 \mu$.

Cells spherical to ovoid with distinct lateral flattening, rounded or tapering to the base; a broad shallow depression runs vertically from the apical margin of the flattened side and dies out one-quarter of the length of the cell; flagella two subequal, arising from apex of depression; chromatophore single, parietal, lobed, granular, dull yellow; nucleus distinct, situated towards the base; pyrenoid central. Fission not observed.

Isolated from sea water in the shell-fish tanks at Conway, North Wales.

This organism is very small and its complete structure is not easy to resolve. Its salient features are the subequal flagella, the pyrenoid and the shallow depression. The first two are characters of the Cryptomonads. The depression is very shallow and rudimentary and no trichocysts can be seen on its margin. It can hardly therefore be considered a furrow. Schiller (1925) describes a rather larger organism from the Adriatic, Hillea fusiformis, which apparently has a depression on one side and a conspicuous nucleus. The species now described appears to have characters sufficiently similar to justify its inclusion in the same genus. In shape and size, however, it is quite unlike $H$. fusiformis Schiller.

\section{Cryptochrysis Pascher}

\section{C. fulva n.sp. (Pl. II, figs. 43-45).}

Cellula nuda, natante, ovata dorsiventraliter depressa, asymmetrica; sulco bene notato a margine anteriore paulo infra apicem perduas tertias partes paginae lateralis decurrente; ordinibus trichocystorum duobus in margine sulci; deest gula; 2 flagellis disparibus in sulco insertis; chromatophoro singulo, magno, plicato, lobato, fulvo; pyrenoide plerumque singula vel in cellulis majoribus 2, centrali, amyli capsula circumdata; nucleo parvo centrali vel posterius inserto. Cellula $3-4 \mu \times 5-7 \mu$.

Cells naked, actively motile, ovoid in dorsal view, slightly flattened on one side though sometimes tapering to the base or with a somewhat truncate apex. A well-marked furrow runs obliquely from a short distance below the apex and dies out two-thirds down the lateral surface; two lines of trichocysts on edge of furrow; gullet not observed; flagella two, subequal, Io-I2 $\mu$ long, arising from lower edge of furrow; chromatophore single, large, folded, lobed, greenish brown; pyrenoid usually single, or two in larger cells, central or one at either end, surrounded by a starch sheath; nucleus small, situated in middle or lower part; contractile vacuole apical, small, single. Multiplication by longitudinal division in motile stage and possibly also in the palmelloid state.

Isolated from the sea water in the shell-fish tanks at Conway, North Wales, I946.

As noted by Pringsheim (1944) for other species, this and the two following 
organisms form palmelloid states in culture, in which the cells are irregularly massed, and the contents are of a richer brown than in the motile cells, containing what appear to be oil granules as well as the pyrenoid. This condition appears to correspond very closely with the palmelloid state of the algadescribed by Reinisch (I9II) as Phaeocapsa marina=Phaeoplax marinus Pascher (I9II), and there seems to be little doubt that the two organisms are very closely related; in fact, a somewhat rounder apex and a sublateral insertion of the flagella seem to be the chief distinguishing points of my species. While the conditions which bring about this palmelloid state have not been ascertained the history of one culture may be relevant. Isolated in April I948 it continued motile and gave satisfactory subcultures until 9 September when a brown deposit was seen in the original culture. This was found to be the palmelloid state together with a number of motile cells. A subculture made from this produced only the palmelloid state from 2 October onwards and was discarded in the following March. In the meantime the original culture remained in the palmelloid state with no vestige of a motile cell from October I948 to May 1949, when motile cells were again seen, being released singly from the palmelloid cells. Meantime two other more recent cultures which had also been palmelloid had become full of motile cells though some 3 months younger. All these cultures, and any subcultures made from them, remained motile throughout the summer months.

It thus seems that the organism can multiply both in the motile and palmelloid stages, and the question arises whether the genus Phaeoplax should be retained. The ease with which other algae are known to form strange palmelloid states in culture, the inconstancy in nature of the formation of such structures, as for example the mucilage tubes in certain diatoms, and the frequency and apparent longevity of the motile state, are against the retention of the genus; the fact that multiplication is possible in the palmelloid state is the chief point in its favour. This and the two following similar organisms apparently do not possess a gullet and are thus included in the genus Cryptochrysis, and it seems logical that the species described by Reinisch should be called C. marina.

The chief distinguishing characters of this species are the single chromatophore, the general shape, and the sublateral insertion of the flagellum.

\section{C. lateralis n.sp. (P1. II, figs. 48-50).}

Cellula nuda, natante, ovata vel obconica lateraliter depressa, asymmetrica, postice acuta; sulco bene notato de margine dorsali triente infra apicem fere usque ad basin paginae ventralis fere recte decurrente; ordinibus trichocystorum duobus in margine sulci; deest gula; 2 flagellis disparibus in sulco insertis; chromatophoris 2, magnis, lobatis, fulvis; pyrenoide singula, centrali, amyli capsula circumdata; cellulis senioribus granulis amyli dispersis praeditis; parte cellulae inferioris hyalina, granulis vel ultra refractivis proedita; nucleo postice inserto; cellula $3-4 \mu \times 5-7 \mu$. 
Cells ovoid to obconical in dorsal view, slightly compressed with lateral flattening, tapering to the base; a well-marked furrow runs almost vertically from the ventral margin, one-third from the apex and dies out almost at the base on the lateral surface; two lines of trichocysts on edge of furrow; gullet not observed; flagella two, subequal, arising from the lower edge of furrow, 5-IO $\mu$ long; chromatophores two, large, lobed, filling most of cell, greenish brown; pyrenoid usually single, medium, obvious, surrounded by starch sheath, more or less centrally placed; older cells with scattered starch grains in addition; contractile vacuoles not observed. Lower portion of cell hyaline containing one or more oscillating refractive granules. Multiplication by longitudinal division, in motile state.

Isolated in August I946 from the shell-fish tanks at Conway.

This species also forms palmelloid states in culture similar to the previous species. Though the insertion of the flagella is almost as low as in the Nephroselmidaceae, this organism is more closely related to the previous species than to the former group and can be easily distinguished by the shape, the two chromatophores, and the almost vertical furrow.

C. virescens n.sp. (P1. II, figs. 46,47 ).

Cellula nuda, natante, ovata, dorsiventraliter depressa; sulco lato bene notato margine dorsali circiter tertia parte infra apicem exoriente atque fere usque ad mediam paginam lateralem oblique decurrente; ordinibus 2 trichocystorum haud bene notatorum in sulco; deest gula; 2 flagellis subaequalibus margine sulci insertis, 6-10 $\mu$ longis; chromatophoro singulo totam cellulam occupante, viridi, glabro; pyrenoide singula, magna, basali; granulis in cellulis senioribus obviis; cellula $3-4 \mu \times 5-7 \mu$.

Cells naked, roundly ovoid, somewhat flattened on ventral side, asymmetrical; a wide well-marked furrow runs obliquely from the lateral margin, about one-third from the apex and dies out about the centre of the lateral surface; two lines of faint trichocysts on the edge of furrow; gullet not observed; flagella two, subequal, arising from the edge of furrow, 6-I2 $\mu$ long; chromatophore single filling the whole cell, green, smooth; pyrenoid single, large, basal; globules possibly oil are present in older individuals. Multiplication by longitudinal division, apparently in the motile state.

Isolated on one occasion from the River Crouch, Essex.

This species can be recognized at once by its colour which, in spite of the wide variation, is unusual in the Cryptophyceae. The furrow is very wide and shallow and this, in apical view, gives the cell a reniform appearance. The dorsiventral compression is also unusual. Nevertheless, its structure with furrow, subequal flagella, large pyrenoid and general appearance is clearly that of a member of the genus Cryptochrysis. 


\section{Cryptomonas Ehrenberg}

C. acuta n.sp. (P1. II, figs. 5I-53).

Cellula nuda, natante, elliptica, dorsiventraliter depressa, basi acuminata vel acuta, apice acuta vel rotundata; sulco bene notato margine ventrali fere quarta parte infra apicem exoriente atque fere usque ad basin fere recte decurrente; ordinibus trichocystorum in sulco valde distinctis; gula sulci tret-quartras partes longitudinis occupante; 2 flagellis subaequalibus in stulco insertis $\mathrm{I} 2-\mathrm{I} 5 \mu$ longis; chromatophoris 2 magnis leviter lobatis, totam cellulam basi excepta occupantibus, granulis paucis exceptis laevibus, fuscis; pyrenoide magna centrali vel parte anteriore inserta, amyli capsula circumdata; nucleo parvo, parte anteriore inserto, granulis basi cellulae oscillantibus. Cellula I2-I $5 \mu \times 4-6 \mu \times 5-7 \mu$.

Cells actively motile and slightly metabolic, elliptical with some dorsiventral flattening, base acuminate or acute, apex acute or rounded; a wellmarked furrow runs almost vertically from the ventral side a quarter of the length from the apex and dies out almost at the base; trichocysts lining the furrow very distinct; gullet in furrow and three-quarters of its length; flagella two, subequal, arising from the upper edge of the furrow, $12-15 \mu$ long; chromatophores two, large, slightly lobed, occupying all except basal portion of the cell, smooth except for a few granules, brown; pyrenoid large, central or in the upper portion, surrounded by starch sheath; nucleus small, in upper part of cell; basal part of cell hyaline and filled with oscillating granules. Multiplication by longitudinal division, apparently only in non-motile state.

Isolated both from the River Crouch and the Conway tanks, but apparently not common.

The gullet in this species is not very marked and it may prove to be intermediate in this respect between the genera Cryptochrysis and Cryptomonas and justify the suggestion of Pringsheim (I944) that it is unreasonable to keep them separate. Oscillating granules similar to the well-known structures in desmids have now been recorded in Chrysophyceae by Carter (1937) and Parke (I949), and this species is an interesting example in the Cryptophyceae. Similar structures, though not actively oscillating, were also apparently present in Cryptochrysis lateralis (see p. I87).

The distinguishing features of this form are the tapered ends, a shape which is rare in this genus and shown only by C. gracilis Skuja (1948), the oscillating bodies and the almost vertical furrow. The sublateral origin of the flagella is also unusual. The presence of a pyrenoid is the most obvious distinction between this and C. gracilis Skuja.

This plant is very sensitive to light and certain chemicals. It disintegrates within $5 \mathrm{~min}$. under the microscope, the pathological symptoms being the extrusion of the protoplast in the form of pseudopodia. It does not change its shape on treatment with iodine but immediately assumes a spherical form on the addition of New Methylene Blue. 


\section{MYXOPHYCEAE \\ CHROOCOCCALES}

Several very minute blue-green organisms with the cells apparently not enveloped in a mucilaginous mass appear from time to time in cultures. One such organism has been identified with Synechococcus elongatus Naeg., while others are suggestive of Pediochloris Geitler and Tetrachloris Pascher, members of the so-called Chlorobacteriaceae. They are often very minute and it is possible that, before their nature can be fully elucidated, methods akin to those used in the taxonomy of bacteria will have to be adopted. The following, however, appears to be a well-marked undescribed species.

\section{Synechococcus Naegeli}

\section{S. bacillaris n.sp. (P1. II, fig. 54)}

Cellula parvula, singula vel e filamentis brevissimis constante, fere spherica, ovata vel cylindrata; deest vagina mucilaginosa; periplasto firmo, mucoso, granulis tenuibus coerules viridibus cellulam implentibus. Incrementum est per cellulam in 2 cellulas transverse divisam. Cellula $\mathrm{I} \cdot 5 \mu \times \mathrm{I} \cdot 7-4 \cdot 5 \mu$.

Cells single or in very short filaments, not enveloped in a sheath of mucilage, almost spherical, ovoid or cylindrical, longest immediately before division; cell wall firm, apparently a thin mucous coat; contents finely granular, uniform, blue-green. Propagation by transverse division of the cells.

First noticed in June 1947 in a tube inoculated with a greenish brown colony from a culture from the Conway tanks growing on a solid medium.

With its nearly spherical cells this species occupies a position between the genera Synechocystis Sauvageau, in which all the cells are spherical, and Synechococcus Naegeli, in which the shape varies between ovoid and cylindrical. In size it is nearest to $S$. elongatus Naeg. (also isolated at Conway) but the cells are only shortly cylindrical and never elongated.

\section{SUMMARY}

Sixteen species of marine algae have been isolated by dilution culture from various coastal waters and are described. They include seven flagellates.

Four are species of Chlorella (C. stigmatophora n.sp., C. salina n.sp., C. ovalis n.sp., C. marina n.sp.): two are species of the closely allied genus Nannochloris (N. maculata n.sp. and N. atomus n.sp.) and one is a species of Stichococcus (S. cylindricus n.sp.). A new species of the Chlamydomonadaceae (Platymonas apiculata n.sp.) is also described. Two others are members of the Chrysophyceae; a very minute form $\mathrm{I}-2 \mu$ diameter, namely Cromulina pusilla n.sp., and an Ochromonad with lateral flagella (Pavlova gyrans n.gen. et sp.). The Cryptophyceae are represented by three species of Cryptochrysis (C. fulvus, n.sp., C. lateralis n.sp. and C. virescens n.sp.), a species of Hillea (H. marina n.sp.) and a species of Cryptomonas (C. acuta n.sp.). A minute blue-green algae, Synechococcus bacillaris n.sp., is also described. 


\section{REFERENCES}

Alvik, G., I934. Plankton-Algen norwegischer Austernpollen. I. Systematik und Vorkommen den Arten. Bergens Museums Ärbok, I934, Nr. 6, 47 pp.

BRUCE, J. R., KNIGHT, M. \& PARKE, M., I940. The rearing of oyster larvae on an algal diet. Fourn. Mar. Biol. Assoc., Vol. 24, pp. 337-74.

Carter, N., 1937. New or interesting algae from brackish water. Arch. Protistenk., Bd. 90, pp. I-68.

Cole, H. A., 1936. Experiments in the breeding of oysters (Ostrea edulis) in tanks, with special reference to the food of the larva and spat. Fish. Invest., Ser. II, Vol. I5, no. 4,28 pp.

1939. Further experiments in the breeding of oysters (Ostrea edulis) in tanks. Fish. Invest., Ser. II, Vol. I6, no. 4, 5I pp.

Cole, H. A. \& KNIGHT JoNES, E. W., I949. Quantitative estimation of marine nannoplankton. Nature, Vol. I64, pp. 694-6.

ConRad, W., I930. Flagellates nouveaux ou peu connus. II. Arch. Protistenk, Bd. 72, pp. $538-53$.

Gross, F., I937. Notes on the culture of some marine plankton organisms. Fourn. Mar. Biol. Assoc., Vol. 21, pp. 753-68.

KRUGER, W., I894. Beiträge zur Kenntnis der Organismen des Saltflusses (sog. Schleimflusses) der Laubbäume. Zopf's Betr. Physiol. Morph. Nied. Organismen, Bd. IV, pp. 69-II6.

Kylin, H., I935. Ueber Rhodomonas, Platymonas und Prasinocladus. Kungl. Fysiogr. Sällsk. Lund Forhandl., Bd. V, nr. 22.

Ministry of Health, I940. The bacteriological examination of water supplies. Rep. on Public Health and Medical subjects, no. 7I (revised ed.).

Naumann, E., I93I. Notizen zur systematik der Süsswasser algen. Arkiv Botan. Vol. I6, pp. I6-18.

Parke, M., I949. Studies on marine flagellates. Fourn. Mar. Biol. Assoc., Vol. 28, pp. $256-85$.

Pascher, A., I9ri. Ueber die Beziehungen der Cryptomonaden zu den Algen. Ber. Deutsch. Bot. Ges., Bd. 29, pp. 193-203.

Pringsheim, E. G., I944. Some aspects of taxonomy in the Cryptophyceae. New Phytol., Vol. 43, pp. I43-50.

ReINisch, O., I9II. Eine neue Phaeocapsaceae. Ber. Dtsch. Bot. Ges., Bd. 29, pp. 77-9.

Reynolds, N., I950. Methods of culturing epiphytic algae. New Phytol., Vol. 49, pp. $155-62$.

SCHILlER, J., I925. Die planktontischen Vegetationen des adriatischen Meeres. B. Arch. Protistenk., Bd. 53, pp. 59-I23.

SkujA, H., I948. Taxonomie des Phytoplanktons Einiger seen in Uppland, Schweden. Symb. Bot. Upsalienses, Vol. 9, nr. 3, 399 pp.

Swaroop, S., 1938. Numerical estimation of $B$. coli by dilution method. Indian Fourn. Med. Res., Vol. 26, p. 353. 


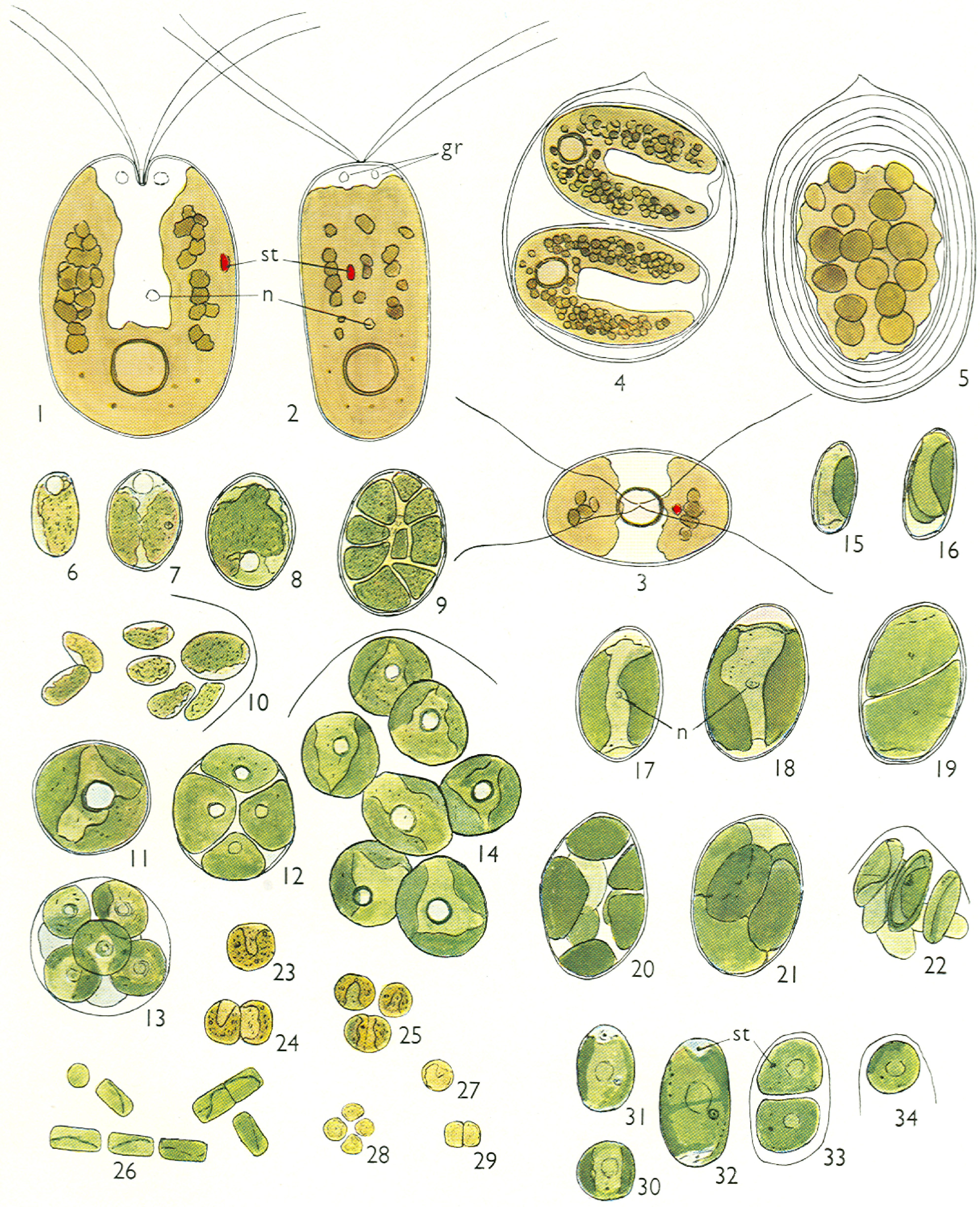




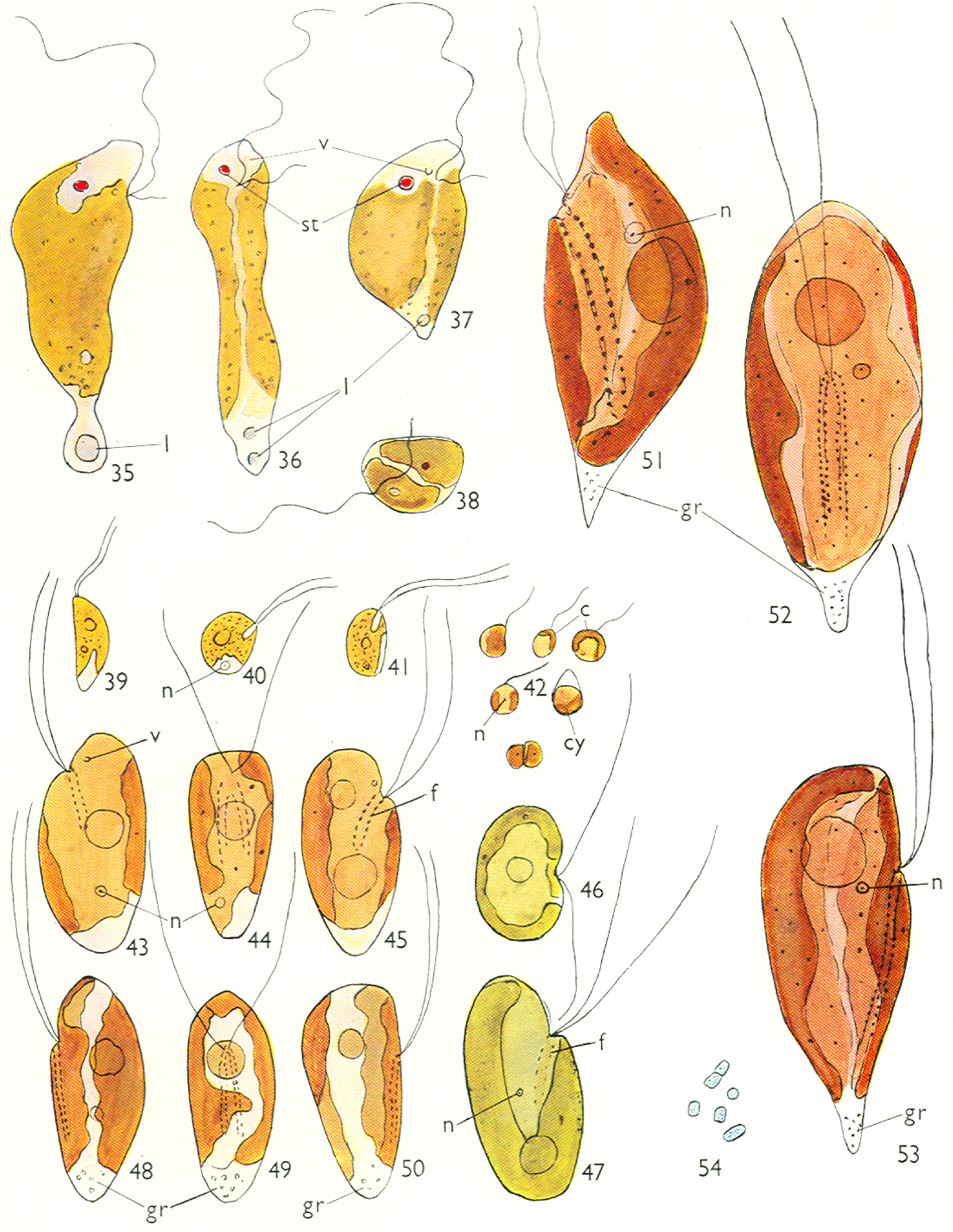




\section{EXPLANATION OF PLATES I AND II}

\section{Plate I}

$$
\text { ( } g r .=\text { granules; } l .=\text { leucosin; } n .=\text { nucleus; } p .=\text { pyrenoid; } s t .=\text { stigma } ; c y .=\text { cyst.) }
$$

Figs. I-5. Platymonas apiculata n.sp. Fig. I, front view; fig. 2, side view; fig. 3, anterior view; fig. 4 , cyst; fig. 5, older single-celled cyst with stratified wall. All $\times 4500$.

Figs. 6-10. Chlorella marina n.sp. Figs. 6-8, cells of varying size; figs. 9, 10, stages in division. All $\times 2250$.

Figs. II-I4. Chlorella salina n.sp. Figs. I2-I4, stages in division. All $\times 2250$.

Figs. I5-22. Chlorella ovalis n.sp. Figs. 15-18, cells of different size; figs. I9-22, stages in division. All $\times 2250$

Figs. 23-25. Nannochloris maculatus n.sp. $\times 2250$.

Fig. 26. Stichococcus cylindricus n.sp. $\times 2250$.

Figs. 27-29. Nannochloris atomus n.sp. All $\times 2250$.

Figs. 30-34. Chlorella stigmatophora n.sp. Figs. 32-34, stages in division. All $\times 2250$.

\section{Plate II}

Figs. 35-38. Pavlova gyrans n.gen. et sp. Figs. 35, 37, two individuals in lateral view; fig. 36, another individual, ventral view; fig. 38 , anterior view. All $\times 4500$.

Figs. 39-4I. Hillea marina n.sp. Fig. 39 dorsal view; figs. 40, 4I, lateral view. All $\times 4500$.

Fig. 42. Cromulina pusilla n.sp. $\times 4500$.

Figs. 43-45. Cryptochrysis fulva n.sp. Figs. 43, 45, lateral views; fig. 44, ventral view. All $\times 4500$.

Figs. 46, 47. Cryptochrysis virescens n.sp. Fig. 46, lateral view; fig. 47, anterior view. Both $\times 4500$.

Figs. 48-50. Cryptochrysis lateralis n.sp. Figs. 48, 50, lateral views; fig. 49, ventral view. All $\times 4500$.

Figs. 5I-53. Cryptomonas acuta n.sp. Fig. 5I, lateral view; fig. 52, another individual, ventral view; fig. 53, the same, lateral view. All $\times 4500$.

Fig. 54. Synechococcus bacillaris n.sp. $\times 4500$. 